\title{
GAMIFICAÇÃO COMO ESTRATÉGIA DE APRENDIZAGEM NO ENSINO REMOTO: RELATO DE EXPERIÊNCIA
}

Semana Online Científica de Educação, 1a edição, de 25/10/2021 a 27/10/2021

ISBN dos Anais: 978-65-81152-18-5

ALMEIDA; FRANCISCA LARISSA RODRIGUES DE ${ }^{1}$, PINHEIRO; MARIA LARA DE ALMEIDA PINHEIRO ${ }^{2}$, LIMA; GLAUCIA POSSO ${ }^{3}$

\section{RESUMO}

INTRODUÇÃO: Com a pandemia da Covid-19 e a necessidade do ensino remoto, fez-se uso da gamificação como método de aprendizagem para estudantes da educação superior. Foi utilizado o kahoot!, uma plataforma de aprendizado baseada em elementos de gamificação para criação de quizzes, nos quais podem ser adicionadas perguntas pelo professor e, essas são convertidas em um jogo com pontuação, interação e ranqueamento. OBJETIVO: Descrever a experiência de gamificação com a utilização da ferramenta kahoot! para melhor compreensão e assimilação do conteúdo ministrado. METODOLOGIA: Estudo descritivo, narrativo do tipo relato de experiência, realizado durante o semestre letivo de 2021 pela docente e monitoras da disciplina de Higiene ofertada para alunos do curso de Nutrição da Universidade Estadual do Ceará. Os quizzes foram elaborados em versão gratuita, contendo dois designs para as questões, questões de verdadeiro ou falso e na forma de múltipla escolha. Foram criados quatro quizzes games, com questões sobre quatro temáticas, cada um com 15 questões, com tempo de resposta para cada questão. RESULTADOS: Durante a construção dos jogos percebeu-se algumas limitações e dificuldades na utilização do kahoot! como a limitação de caracteres nas perguntas e respostas, o que restringe um pouco o uso do aplicativo, permitindo somente textos bem diretos e objetivos. No entanto, o uso da ferramenta despertou a competitividade e a interação dos alunos, de forma dinâmica e simples, garantindo grande adesão da turma. Essa ferramenta ainda incentivou a interação entre os alunos e a professora e entre os alunos, e facilitou assim a aprendizagem. CONCLUSÃO: O uso da plataforma foi garantia de participação da turma, sendo aplicada 4 vezes e atingindo níveis elevados de acertos, levando as monitoras juntamente com a professora da disciplina a explorarem cada vez mais seu uso durante as aulas como forma de aprimorar os temas discutidos.

PALAVRAS-CHAVE: Aprendizagem, Ensino remoto, Gamificação 